\title{
Does stock market development promote economic growth? A bounds testing analysis for Bangladesh
}

\author{
Md. Abu Hasan \\ Assistant Professor of Economics, Bangladesh Civil Service (General Education), \\ Ministry of Education, Bangladesh \\ e-mail correspondence: hhafij@yahoo.com
}

\begin{abstract}
The aim of this paper is to investigate the linkage between stock market development and real economic growth in Bangladesh using time series data from 1981 to 2017 employing Autoregressive Distributed Lag (ARDL) bounds testing cointegration procedure and Error Correction Model (ECM). The bounds testing cointegration procedures reveal that stock market size has a significant long run impact on real economic growth in Bangladesh at 5\% significance level. The results of the estimated ARDL-ECM models show that a highly significant long-run causality is directing from stock market development to real economic growth. The negative and significant error correction term implies that $81 \%$ of the last year's disequilibrium is corrected this year by changes in real economic growth. Finally, we find that there is no causality running between real economic growth and stock market development in the short run. Stock market performance prompts real economic growth in the long run though the contribution of the stock market in Bangladesh related to money market is still in a transition period. Moreover, bank dominating financial system of Bangladesh is nearly seeming close to the catastrophe bring about by massive nonperforming loans and series of banking scams. Thus, policymakers of Bangladesh should give a boost to the stock market as a complimentary financial system with the banking sector such that economic growth will be contributed better than the results of this study demonstrate.
\end{abstract}

Keywords: Economic Growth, Stock Market Size, Autoregressive Distributed Lag (ARDL) Model, Error Correction Model (ECM).

JEL classification: L11, O47, D40.

\section{INTRODUCTION}

Researchers and policy makers pay a lot of attention to find out the ways in which economic growth can be enhanced as it is judged as the prime economic objective for any economy. Since stock market is considered as an engine for growth, this study pays a special effort to better understand the relationship between stock market development and economic growth. From the time when the pioneering contributors, such as, Schumpeter (1934), Goldssmith (1969), Shaw (1973) and McKinnon (1973) reveal the positive relationship between financial development and economic growth, the thought generates an important issue of debate. In their literature, Ahmed and Mmolainyane (2014) argue that the causal relationships between financial development and economic growth are sketched along three lines: (i) financial 
deepening promotes economic growth, (ii) economic growth stimulates financial development and (iii) financial development and economic growth influence each other. Shaw (1973) and McKinnon (1973) contend the link from financial deepening to growth, while Goldssmith (1969) supports the opposite direction. More interestingly, Luintel and Khan (1999) find the bi-directional causality between financial development and economic growth. Though, the initiatives of relating economic growth to the financial development have performed long ago, that mainly emphasized the role of the banking sector in economic growth.

In the past few decades, the world stock markets obtained more attention in consequence of the growing importance to allocate the necessary capital required for the consistent growth of the economy. The economic theory suggests that the stock market impacts on aggregate demand through aggregate consumption, savings and investment. A well- performed stock market must increase savings, which leads to allocate capital to the industries for productive investments, and it must generate new employment, more output, and finally an increase in the rate of economic growth. Moreover, a substantial body of literature suggests that financial market development plays a significant role in economic growth through fostering savings mobilization, easing risk management, promoting technological transfer and reducing information and transaction costs (Ahmed and Mmolainyane, 2014). Accordingly, researchers have been focused research on the impact of stock market development on economic growth as the issues contain various implications. A handsome amount of study resolve on the ambiguous relationship between stock market development and economic growth for the last two decades. Several studies, such as, Levine (1991), Levine and Zervos (1996), Atie and Jovanovic (1993), Olweny and Kimani (2011), Nurudeen (2009), and Deb and Mukherjee (2008) claim that stock market development significantly promotes economic growth of a country both directly and indirectly. Jahfer and Inoue (2014) find that stock market development causes economic growth, but there is no evidence of causality from economic growth to stock market development in Japan. In contrast, Dritsaki and Melina (2005) reveal a unidirectional causality from economic development to stock market for Greece. Ibrahim (2011) finds a dual-directional causality between the stock market capitalization and real GDP for Thailand. Till date, a few studies in Bangladesh perspective also reveal the ambiguous results. Applying Johansen Cointegration and VECM, Hasan et al. (2017) find a bi-directional causality between real economic growth and stock market development in Bangladesh for the period from 1981 to 2014 . They comment that real economic growth leads to stock market capitalization ratio and turnover ratio in Bangladesh, while turnover ratio leads to economic growth. Hossain and Kamal (2010) investigate the causal relationship between stock market development and economic growth in Bangladesh using the Engle-Granger causality and ML tests. They reveal that the stock market development strongly influences the economic growth in Bangladesh economy, but there is no causation from economic growth to stock market development. In contrast, Haque and Fatima (2011) explore the relationship between stock market development and long run per capita growth rate of Bangladesh. Employing two dynamic panel models for the sample period of 1980 to 2007, they find that stock markets in Bangladesh have no influence on the real economic activity.

The present study examines the link between stock market development and the economic growth in Bangladesh as rare studies have been done so far in the context of Bangladesh. Moreover, since 1990 to 2017, average real GDP growth and average stock 
market size increased at average $5.51 \%$ and $11.29 \%$ respectively. Thus, there should a relationship between economic growth and stock market as the economy is growing associated with stock market. Al-Jafari et al. (2011) explore that over the past several decades, emerging countries have experienced persistent and high rates of economic growth. They also comment that while many factors explain economic growth, trade and capital market liberalization have played an important role.

The present study follows this line of thinking and sets the specific objectives are to investigate the existence of long run relationships between stock market development and economic growth, and to examine the direction of causal relationships between stock market development and economic growth. Economic growth is a straightforward concept. It is measured by the growth rate of real GDP at constant prices. Stock market development is a multi-dimensional concept. It is generally evaluated by stock market size, market liquidity, market concentration, market integration and the legal rule in the market. This study uses market size and market liquidity as a measure for stock market development of Bangladesh. The conceptual framework as brought out from the literature review in this study is illustrated in the figure 1 below.

\section{Stock Market Development:}

1. Market Size: Market Capitalization Ratio

2. Market Liquidity: Turnover Ratio

\section{Economic Growth:}

Growth of GDP in real terms

Figure 1. Conceptual Framework

This study contributes to the existing literature in numerous ways. First, to the best of our knowledge, this is the first study to explore the association between stock market development and the economic growth employing ARDL-bounds testing method in reference to Bangladesh. Second, this study uses data since 1981 to 2017, while the Dhaka Stock Exchange (DSE) restarted its trading only in 1976 after the independence in 1971. Thus, this study will provide valuable insights. Finally, the results of the study will add valuable knowledge to the existing literature in terms of an emerging economy.

\section{METHODOLOGY}

\section{Data and data sources}

Bangladesh has two stock exchanges: Dhaka Stock Exchange (DSE) and Chittagong Stock Exchange (CSE). Dhaka Stock Exchange is the oldest and largest stock exchange in Bangladesh. Thus, the study purposefully selects DSE as a sample of the stock market of Bangladesh. On the other hand, the performance of the overall economy is targeted and measured by the growth in GDP in constant prices. The current study concentrates on Bangladesh economy covering a period of thirty seven years (1981-2017). Any study of stock market development should preferably be based on monthly data. But given the fact that monthly GDP figures in Bangladesh are not available, the study uses yearly data of GDP growth rate and indicators of stock market development.

This study uses market size and market liquidity as a measure for stock market development of Bangladesh. Specifically, we use the following indicators of stock market development: 
Market Size: The market capitalization ratio is the main indicator that used as a measure of stock market size and depth. The Market Capitalization Ratio (MCR) is defined as the market capitalization of stocks divided by GDP i.e., Market Capitalization to GDP $=\frac{\text { Stock Market Capitalization }}{\text { GDP in Current Market Price }} \times 100$. In terms of economic significance, market size, i.e., market capitalization ratio is positively related with the ability to mobilize capital and diversify risk on an economy.

Market Liquidity: Stock market liquidity is the ability of a market to easily buy and sell securities without having to reduce its price very much. The turnover ratio is the main indicator that used as a measure of stock market liquidity. The Turnover Ratio (TR) ratio measures stock market trading compared with the size of the Economy. Turnover Ratio $=\frac{\text { Value of Shares Traded }}{\text { Stock Market Capitalization }} \times 100$. A small liquid market generally has a high turnover ratio.

Data of market capitalization, turnover, GDP in current local prices and real GDP growth rate are collected from various issues of the Monthly Economic Trend published by Bangladesh Bank, Bangladesh Economic Review (2017), Arif (2014) and World Development Indicators of World Bank (2017).

\section{Econometric analysis}

The study uses quite a lot of econometric analysis to investigate the relationship and the direction of causality between the stock market development and economic growth in Bangladesh. Unit root tests and Autoregressive Distributed Lag (ARDL) bounds testing cointegration analysis are used to test the stationarity and multiple long run relationship respectively. ARDL-Error Correction Model (ARDL-ECM) is employed to test the long run causality, short run to long run dynamic adjustment of the system of cointegrated variables and the short run causality among the variables.

\section{Testing for stationarity}

The first step of the econometric analysis requires a test for stationarity considering that the variables selected in this paper are time series which are usually non-stationary. Two extensively used unit root test, namely, Augmented Dickey Fuller (ADF) and Phillips-Peron (PP) test are employed to avoid the problem of spurious regression and to examine the stationarity of the time series. ADF is the augmented form of Dickey Fuller test. The ADF test is performed using the following equation:

$$
\Delta \mathrm{Y}_{\mathrm{t}}=\alpha+\beta \mathrm{T}+\gamma \mathrm{Y}_{\mathrm{t}-1}+\delta_{\mathrm{i}} \sum_{\mathrm{i}=1}^{\mathrm{m}} \Delta \mathrm{Y}_{\mathrm{t}-\mathrm{i}}+\varepsilon_{\mathrm{t}}
$$

where $\alpha$ is an interecpt (constant), $\beta$ is the coefficient of time trend T, $\gamma$ and $\delta$ are the parameters where, $\gamma=\rho-1, \Delta \mathrm{Y}$ is the first difference of $\mathrm{Y}$ series, $\mathrm{m}$ is the number of lagged first differenced term, and $\varepsilon$ is the error term.

Phillips and Perron (1988) have developed a non-parametric unit root conception. The PP test is modified from Dickey-Fuller test so that serial correlation does no longer affect their asymptotic distribution. The PP test test is performed using the following equation:

$$
\Delta \mathrm{Y}_{\mathrm{t}}=\alpha+\beta \mathrm{T}+\gamma \mathrm{Y}_{\mathrm{t}-1}+\varepsilon_{\mathrm{t}}
$$

where $\alpha$ is a constant, $\beta$ is the coefficient of time trend T, $\gamma$ is the parameter and $\varepsilon$ is the error term.

\section{ARDL Bounds Cointegration and Error Correction Model}

The ARDL bounds testing procedure of cointegration are sequentially developed by Pesaran and Pesaran (1997), Pesaran and Shin (1999), and Pesaran, Shin and Smith 
(2001). Pesaran and Shin (1999) argue that ARDL bounds test method is relatively more efficient and performs better in small data sizes, while Johansen and Juselius cointegration model needs larger samples for the results to be valid. We employ the ARDL model as the variables selected in this study are in mixed order and ARDL model provides robust results for small sample sizes as in the case in this study. We construct the long-run models as follows:

$$
\begin{aligned}
& \mathrm{GDP}_{\mathrm{t}}=\alpha_{1}+\beta_{1} \mathrm{MCR}_{\mathrm{t}}+\beta_{2} \mathrm{TR}_{\mathrm{t}}+\varepsilon_{1 \mathrm{t}} \\
& \mathrm{MCR}_{\mathrm{t}}=\alpha_{1}+\beta_{1} \mathrm{GDP}_{\mathrm{t}}+\beta_{2} \mathrm{TR}_{\mathrm{t}}+\varepsilon_{1 \mathrm{t}} \\
& \mathrm{TR}_{\mathrm{t}}=\alpha_{1}+\beta_{1} \mathrm{GDP}_{\mathrm{t}}+\beta_{2} \mathrm{MCR}_{\mathrm{t}}+\varepsilon_{1 \mathrm{t}}
\end{aligned}
$$

where $\alpha_{\mathrm{i}}$ are intercept terms, $\beta_{\mathrm{i}}$ are the coefficients and $\varepsilon_{\mathrm{i}}$ are the error terms.

Equation (3), (4) and (5) can be written in the following conditional error correction model (ECM) version of the ARDL in order to carry out the bounds testing procedure:

$$
\begin{aligned}
\Delta \mathrm{GDP}_{\mathrm{t}}= & \mathrm{c}_{1}+\pi_{1} \mathrm{GDP}_{\mathrm{t}-1}+\pi_{2} \mathrm{MCR}_{\mathrm{t}-1}+\pi_{3} \mathrm{TR}_{\mathrm{t}-1}+\sum_{\mathrm{i}=1}^{\rho} \theta_{\mathrm{i}} \Delta \mathrm{GDP}_{\mathrm{t}-\mathrm{i}}+ \\
& \sum_{\mathrm{i}=1}^{\rho} \emptyset_{\mathrm{i}} \Delta \mathrm{MCR}_{\mathrm{t}-\mathrm{i}}+\sum_{\mathrm{i}=1}^{\rho} \delta_{\mathrm{i}} \Delta \mathrm{TR}_{\mathrm{t}-\mathrm{i}}+\mathrm{u}_{1 \mathrm{t}} \\
\Delta \mathrm{MCR}_{\mathrm{t}}= & \mathrm{c}_{2}+\pi_{1} \mathrm{MCR}_{\mathrm{t}-1}+\pi_{2} \mathrm{GDP}_{\mathrm{t}-1}+\pi_{3} \mathrm{TR}_{\mathrm{t}-1}+\sum_{\mathrm{i}=1}^{\rho} \theta_{\mathrm{i}} \Delta \mathrm{GDP}_{\mathrm{t}-\mathrm{i}}+ \\
& \sum_{\mathrm{i}=1}^{\rho} \emptyset_{\mathrm{i}} \Delta \mathrm{MCR}_{\mathrm{t}-\mathrm{i}}+\sum_{\mathrm{i}=1}^{\rho} \delta_{\mathrm{i}} \Delta \mathrm{TR}_{\mathrm{t}-\mathrm{i}}+\mathrm{u}_{1 \mathrm{t}} \\
\Delta \mathrm{TR}_{\mathrm{t}}= & \mathrm{c}_{3}+\pi_{1} \mathrm{TR}_{\mathrm{t}-1}+\pi_{2} \mathrm{GDP}_{\mathrm{t}-1}+\pi_{3} \mathrm{MCR}_{\mathrm{t}-1}+\sum_{\mathrm{i}=1}^{\rho} \theta_{\mathrm{i}} \Delta \mathrm{GDP}_{\mathrm{t}-\mathrm{i}}+ \\
& \sum_{\mathrm{i}=1}^{\rho} \emptyset_{\mathrm{i}} \Delta \mathrm{MCR}_{\mathrm{t}-\mathrm{i}}+\sum_{\mathrm{i}=1}^{\rho} \delta_{\mathrm{i}} \Delta \mathrm{TR}_{\mathrm{t}-\mathrm{i}}+\mathrm{u}_{1 \mathrm{t}}
\end{aligned}
$$

where equation (6), (7) and (8) are termed as model 1, 2 and 3 respectively.

The first parts of the above equations represent the long-run dynamics of the models and the second parts show the short-run relationship in which $\Delta$ signifies the first difference operator. $\mathrm{c}_{\mathrm{i}}(\mathrm{i}=1,2,3)$ shows constants, $\pi_{\mathrm{i}}(\mathrm{i}=1 . .3)$ denotes coefficients on the lagged levels, $\theta \mathrm{i}, \phi_{\mathrm{i}}$ and $\delta_{\mathrm{i}},(\mathrm{i}=1 \ldots \rho)$ denote coefficients on the lagged variables, and finally $u_{i}(i=1 \ldots 3)$ stands for error terms. $\rho$ signifies the maximum lag length. We estimate the equations (6) to (8) in order to test the long-run relationship where the null and alternative hypotheses are as follows: $H_{0}: \pi_{1}=\pi_{2}=$ $\pi_{3}=0$ (No long run relationship ); $H_{1}: \pi_{1} \neq \pi_{2} \neq \pi_{3} \neq 0$ (Long run relationship exists). Then we will estimate the long- and short-run coefficients of the same equations only if we find a long-run relationship in the first step.

\section{FINDINGS}

\section{Stationarity results}

The unit root test results are given in the following Table 1. Both ADF and PP tests are conducted using trend and intercept, intercept, and none term of the models. The findings of the ADF and PP tests yield significantly similar results at level and first difference. Nevertheless, both test provides evidence of stationarity of all variables in their first difference. It can be noticed that the null hypothesis of a unit root at the level are accepted in all cases for MCR and TR as test statistics are lower than the critical values. GDP appears to be stationary in the level with intercept, and intercept and trend, however; nonstationary in the level when none term is considered. Since none of the variables are $I(2)$ and the variables are in mixed order, we are decided to use the ARDL bound testing method to detect the presence of cointegration among the variables. 
Table 1. Unit root test results

\begin{tabular}{lcccccc}
\hline Variables & \multicolumn{2}{c}{ Augmented Dickey Fuller (ADF) } & \multicolumn{3}{c}{ Phillips-Peron (PP) } \\
\cline { 2 - 7 } & None & Intercept & $\begin{array}{c}\text { Intercept } \\
\text { and trend }\end{array}$ & None & Intercept & $\begin{array}{c}\text { Intercept } \\
\text { and trend }\end{array}$ \\
\hline GDP & 0.53 & -1.66 & $-8.30^{*}$ & -5.56 & $-3.84^{*}$ & $-10.61^{*}$ \\
& $(0.83)$ & $(0.44)$ & $(0.00)$ & $(0.47)$ & $(0.00)$ & $(0.00)$ \\
MCR & -0.45 & -1.16 & -2.24 & -5.51 & -1.23 & -2.24 \\
& $(0.51)$ & $(.68)$ & $(0.45)$ & $(0.49)$ & $(0.65)$ & $(0.45)$ \\
TR & -0.91 & -1.81 & -2.36 & $-5.08^{*}$ & -1.93 & -2.56 \\
& $(0.32)$ & $(0.37)$ & $(0.39)$ & $(0.00)$ & $(0.32)$ & $(0.30)$ \\
$\Delta$ GDP & $-11.2^{*}$ & $-4.44^{*}$ & $-4.43^{*}$ & $-5.48^{*}$ & $-22.03^{*}$ & $-21.62^{*}$ \\
& $(0.00)$ & $(0.00)$ & $(0.00)$ & $(0.00)$ & $(0.00)$ & $(0.00)$ \\
$\Delta$ MCR & $-5.49^{*}$ & $-5.49^{*}$ & $-5.42^{*}$ & $-4.65^{*}$ & $-5.48^{*}$ & $-5.40^{*}$ \\
& $(0.00)$ & $(0.00)$ & $(0.00)$ & $(0.00)$ & $(0.00)$ & $(0.00)$ \\
$\Delta$ TR & $-5.08^{*}$ & $-5.04^{*}$ & $-4.96^{*}$ & $-2.28^{* *}$ & $-5.04^{*}$ & $-4.96^{*}$ \\
& $(0.00)$ & $(0.00)$ & $(0.00)$ & $(0.02)$ & $(0.00)$ & $(0.00)$ \\
\hline
\end{tabular}

Note: ${ }^{*}$ and ${ }^{* *}$ indicate stationary at $1 \%$ and 5\% levels respectively using MacKinnon (1996) critical values. P-values are presented in first brackets. 5\% critical value is 1.95 for the ADF and PP statistic at level and first differences of the variables.

\section{ARDL Bounds Cointegration and ECM Results}

In order to estimate the equation (6) to (8), an appropriate lag length must be determined. Thus, five different criteria, namely Likelihood Ratio (LR), Final Prediction Error (FPE), Akaike Information Criteria (AIC), Schwarz Information Criteria (SIC) and Hannan-Quinn Information Criteria (HQ) are used to determine the lag lengths used in the VAR. Table 2 presents the results for each criterion with a maximum of 4 lags. It is clear that LR, FPE, SIC and HQ criteria stand in favor of 1 lag, while AIC criteria suggests for 4 lags.

Table 2. Optimal lag lengths of the VAR model

\begin{tabular}{lcccccc}
\hline Lags & LogL & LR & FPE & AIC & SIC & HQ \\
\hline 0 & -322.87 & NA & 75806.36 & 19.75 & 19.89 & 19.79 \\
1 & -269.13 & $94.44^{*}$ & $5056.07^{*}$ & $17.04^{*}$ & $17.58^{*}$ & $17.22^{*}$ \\
2 & -261.43 & 12.13 & 5558.65 & 17.12 & 18.07 & 17.44 \\
3 & -254.93 & 9.06 & 6726.83 & 17.27 & 18.63 & 17.73 \\
4 & -241.64 & 16.10 & 5598.38 & $17.01^{*}$ & 18.78 & 17.60 \\
\hline
\end{tabular}

Note: * indicates lag order selected by the criterion.

The presence of residual serial correlation makes the result less efficient. Thus, we proceed to conduct Lagrange Multiplier (LM) tests for each suggested lags up to maximum 4 lags (Table 3). The p-values associated with the LM tests strongly reject the presence of serial correlation in the estimated residuals generated from VAR (1) and VAR (4) model. Though, we can accept either VAR (1) or VAR (4), we decide to accept VAR (1) model for cointegrating analysis as sample sizes of this study are small.

Table 3. Residual serial correlation LM tests for the VAR model

\begin{tabular}{lcccc}
\hline \multirow{2}{*}{ Lags } & \multicolumn{3}{c}{ 4 Lags } & \multicolumn{3}{c}{ 1 Lag } \\
\cline { 2 - 5 } & LM-Stat & P-Values & LM-Stat & P-Values \\
\hline 1 & 7.91 & 0.54 & 14.28 & 0.11 \\
2 & 5.52 & 0.79 & 5.95 & 0.75 \\
3 & 4.53 & 0.87 & 9.30 & 0.41 \\
4 & 11.97 & 0.22 & 11.29 & 0.26 \\
\hline
\end{tabular}


Table 4 shows that the computed F- statistics for three ARDL $(1,1,1)$ models based on the Schwarz Information Criteria (SIC). The computed F- statistics for model 1 is 6.15 that is higher than the upper bound critical value of 5 at $1 \%$ level of significance. The computed F- statistics for model 2 and 3 are 0.59 and 1.41 respectively that are lower than the upper bound critical value of 3.87 at $5 \%$ level of significance. Therefore, the long-run relationship among the variables exist when real economic growth (GDP) is dependent on stock market development (MCR and TR).

Table 4. Results of ARDL bounds cointegration test

\begin{tabular}{|c|c|c|c|c|c|c|c|}
\hline \multirow{2}{*}{$\begin{array}{l}\text { Model: } \\
\text { Dependent } \\
\text { variable }\end{array}$} & \multirow[t]{2}{*}{$\begin{array}{l}\text { Forcing } \\
\text { variables }\end{array}$} & \multirow[t]{2}{*}{ F-Statistics } & \multicolumn{2}{|c|}{$\begin{array}{c}5 \% \text { Critical } \\
\text { bounds }\end{array}$} & \multicolumn{2}{|c|}{$\begin{array}{c}1 \% \text { Critical } \\
\text { bounds }\end{array}$} & \multirow[t]{2}{*}{ Remarks } \\
\hline & & & $\mathrm{I}(0)$ & $\mathrm{I}(1)$ & $\mathrm{I}(0)$ & $\mathrm{I}(1)$ & \\
\hline 1: GDP & MCR and TR & $6.15^{*}$ & 3.1 & 3.87 & 4.13 & 5 & Present \\
\hline 2: MCR & GDP and TR & 0.59 & 3.1 & 3.87 & 4.13 & 5 & Absent \\
\hline 3: TR & GDP and MCR & 1.41 & 3.1 & 3.87 & 4.13 & 5 & Absent \\
\hline
\end{tabular}

Note: "denotes rejection of the null hypothesis at the $1 \%$ level.

Table 5 illustrates the long run coefficients of model 1. The long-run coefficient of MCR is significant at 5\% significance level suggesting that market capitalization ratio has a significant long run impact on GDP. The ARDL results for model 1 (when GDP is a dependent variable) show that stock market development is positively related with economic growth. The result implies that a $100 \%$ increase in market capitalization ratio contributes to 7\% increase in GDP in Bangladesh.

Table 5. Long-Run coefficients for ARDL $(1,1,1)$ : model 1

\begin{tabular}{lllll}
\hline Model & Variable & Coefficient & P-value & Long-run cointegration equation \\
\hline 1: GDP & MCR & $0.07^{* *}$ & 0.02 & GDP $=4.24+0.07 \mathrm{MCR}+0.01 \mathrm{TR}$ \\
& TR & 0.01 & 0.51 & \\
\hline
\end{tabular}

Note: ${ }^{*}$ denotes the coefficients are significant at the $5 \%$ level.

The short-run dynamics along with the error correction term (ECT) results are reported in Table 6. The results of the estimated ARDL-ECM models clearly indicate that the coefficients of error correction terms of the model 1 is negative and statistically significant at the $1 \%$ level of significance. It suggests that a highly significant long-run causality is also directing from stock market development (MCR and TR) to economic growth (GDP). The error correction term is -0.81 , that implies that GDP requires about seven months to converge to equilibrium after being shocked. In other words, $81 \%$ of the last year's disequilibrium is corrected this year by changes in economic growth. But, the ECM results also explore that the short-run impact of the variables on GDP is statistically insignificant.

Table 6. Error correction estimates

\begin{tabular}{lllll}
\hline Variable & Coefficient & Std. Error & t-statistic & P-value \\
\hline $\mathrm{D}(\mathrm{MCR})$ & -0.02 & 0.05 & -0.36 & 0.72 \\
$\mathrm{D}(\mathrm{TR})$ & 0.01 & 0.01 & 1.01 & 0.32 \\
CointEq(-1) & $-0.81^{*}$ & 0.16 & -5.20 & 0.00 \\
\hline
\end{tabular}

Note: ${ }^{*}$ denotes the coefficients are significant at the $1 \%$ level.

In order to verify the robustness of the models, diagnostic checking of the estimated models have been carried out in terms of conventional multivariate residualbased tests for serial correlation, normality and heteroscedasticity (Table 7). At 5\% 
level of significance, the Lagrange Multiplier (LM) test for autocorrelation indicates the absence of autocorrelation and ARCH Chi-square test for heteroskedasticity indicates the absence of heteroskedasticity. The model also passes the Jarque- Bera normality test at 5 percent suggesting that the error is normally distributed in the models.

Table 7. Results of diagnostic tests

\begin{tabular}{lccc}
\hline & \multicolumn{3}{c}{ Diagnostic tests } \\
\cline { 2 - 4 } & $\begin{array}{l}\text { Serial } \\
\text { correlation LM }\end{array}$ & $\begin{array}{c}\text { ARCH } \\
\text { heteroskedasticity }\end{array}$ & $\begin{array}{l}\text { Jarque-Bera } \\
\text { normality }\end{array}$ \\
\hline Statistics & 3.49 & 0.48 & 0.69 \\
P-Value & 0.07 & 0.49 & 0.71 \\
\hline
\end{tabular}

Finally, cumulative sum of recursive residuals (CUSUM) and cumulative sum of squares of the recursive residuals (CUSUMSQ) tests are employed to test for parameter stability. Figure 2 plots the CUSUM and CUSUM of squares statistics. The plotted points for the CUSUM and CUSUMSQ statistics stay within the critical bounds of a 5\% level of significance. Thus, these statistics confirm the stability for all coefficients of the estimated equations.

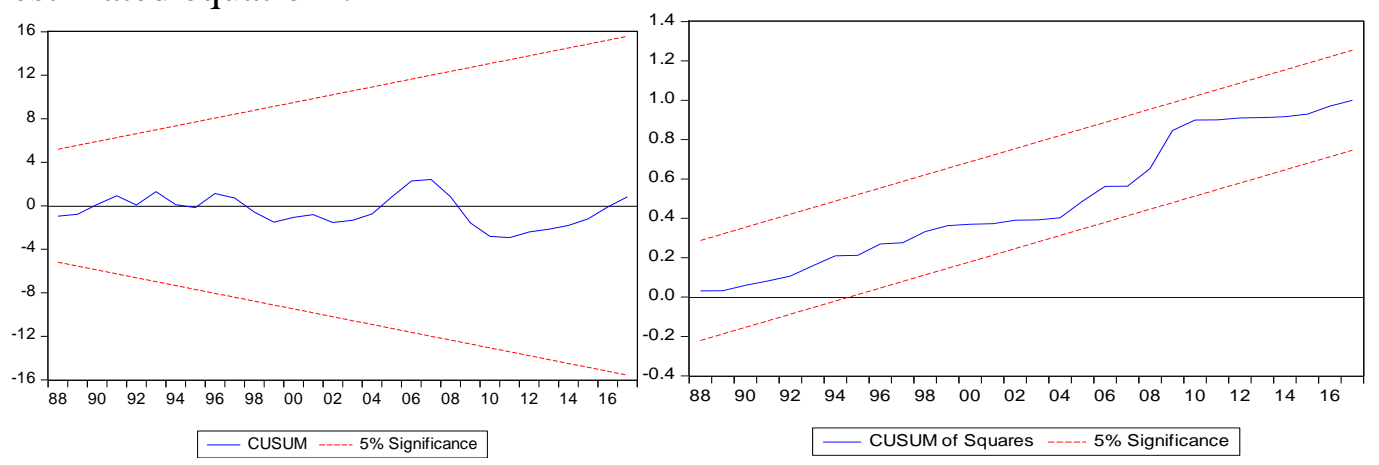

Figure 2. Plots of CUSUM and CUSUMSQ stability test

The long run results of the present study consistent with Shaw (1973), McKinnon (1973), Nurudeen (2009) and Jahfer and Inoue (2014) as well as some other studies that stock market development stimulates economic growth. Our findings are not consistent with the results of Boubakari and Jin (2010) as they reject any direction of causality between stock market and economic growth in the countries where the stock markets are small and less liquid. Contrary to Haque and Fatima (2011), this study finds an evident partially similar to Hossain and Kamal (2010) and Hasan et al. (2017) that stock market development causes economic growth in the long run in Bangladesh.

\section{CONCLUSIONS AND RECOMMENDATIONS}

\section{Conclusions}

Employing the bounds testing cointegration procedure and ARDL-error correction model, this paper investigates the long run and short run dynamics of stock market development and economic growth in Bangladesh over the period from 1981 to 2017. The bounds testing cointegration procedures reveal that a significant long-run relationship among the variables exist when real economic growth (GDP) is dependent on stock market size (market capitalization ratio-MCR) and stock market liquidity (turnover ratio-TR). The long-run coefficient of $\mathrm{MCR}$ is significant at 5\% significance level suggesting that stock market size has a significant long run impact on real 
economic growth. Specifically, the result implies that a $100 \%$ increase in market capitalization ratio contributes to $7 \%$ increase in real economic growth in Bangladesh. The results of the estimated ARDL-ECM models show that a highly significant longrun causality is directing from stock market development (MCR and TR) to real economic growth in Bangladesh. The error correction term implies that $81 \%$ of the last year's disequilibrium is corrected this year by changes in real economic growth. Finally, we find that there is no short run significant relationship existed between stock market development and economic growth in Bangladesh.

\section{Recommendations}

Stock market performance prompts real economic growth in the long run though the contribution of the stock market in Bangladesh related to money market is still in a transition period. Thus, policymakers of Bangladesh should give a boost to the stock market as bank dominating financial system of Bangladesh is nearly seeming close to the catastrophe bring about by massive nonperforming loans and series of banking scams. The studies, such as, Garcia and Liu (1999) and Dima, Dinca and Spulbar (2014) may be a strategic way out for the policymakers of Bangladesh as they uncover that capital markets' development supports a stable evolution in the banking sector. Finally, we can comment that stock market of Bangladesh may be a complimentary financial system with the banking sector such that economic growth will be contributed better than the results of this study demonstrate.

\section{REFERENCES}

Ahmed, A.D. \& Mmolainyane, K.K. (2014). Financial integration, capital market development and economic performance: empirical evidence from Botswana. Economic Modelling, 42: 1-14. doi:10.1016/j.econmod.2014.05.040

Al-Jafari, M. K., Salameh, R.M. and Habbash, M.R. (2011). Investigating the relationship between stock market returns and macroeconomic variables: evidence from developed and emerging markets. International Research Journal of Finance and Economics, 79: 6-30.

Arif, K.M. (2014). Dynamics of capital market in Bangladesh. Unpublished PhD Thesis, Islamic University, Kushtia, Bangladesh.

Atje, R. \& Jovanovic, B. (1993). Stock markets and development. European Economic Review, 37(2-3): 632-640.

Boubakari, A. \& Jin, D. (2010). The role of stock market development in economic growth: evidence from some Euronext countries. International Journal of Financial Research, 1(1): 14-20. doi:10.5430/ijfr.v1n1p14

Deb, S.G. \& Mukherjee, J. (2008). Does stock market development cause economic growth? a time series analysis for Indian economy. International Research Journal of Finance and Economics, 21: 142-149.

Dima, B. Dinca, M.S. \& Spulbar, C. (2014). Financial nexus: efficiency and soundness in banking and capital markets. Journal of International Money and Finance, 47: 100-124. http://dx.doi.org/10.1016/j.jimonfin.2014.05.002

Dritsaki, C. and Melina B. (2005). The Causal Relationship between stock, Credit Market and Economic Development: An Empirical Evidence for Greece, Economic Change and Restructuring, 38: 113-127.

Garcia, V.F. \& Liu, L. (1999). Macroeconomic determinants of stock market development. Journal of Applied Economics, 2(1): 29-59. 
Goldsmith, R.W. (1969). Financial structure and development. New Haven: Yale University Press.

Haque, M.H. \& Fatima, N. (2011). Influences of stock market on real economy: a case study of Bangladesh. The Global Journal of Finance and Economics, 8(1): 4960.

Hasan, M.A., Sanaullah, M. and Zaman, A. (2017). Cointegration and Causality between Stock Market Development and Economic Growth in Bangladesh. Paper presented at the $20^{\text {th }}$ biennial conference organized by Bangladesh Economic Association on December 21-23, 2017, Dhaka, Bangladesh. Retrieved from http://bea-bd.org/site/images/pdf/new17/40.pdf

Hossain, M.F. \& Kamal, K.M.M. (2010). Does stock market development cause economic growth? a time series analysis for Bangladesh economy. Paper presented at the International Conference on Applied Economics, Department of Economic Sciences, National and Kapodistrian University of Athens. Retrieved from http://kastoria.teikoz.gr/icoae/?p=389\#more-389

Ibrahim, M. H. (2011). Stock Market Development and Macroeconomic Performance in Thailand. Inzinerine Ekonomika-Engineering Economics, 22(3), 230-240. http://dx.doi.org/10.5755/j01.ee.22.3.513

Jahfer, A. \& Inoue, T. (2014). Financial development and economic growth : the role of stock market in Japan. International Review of Business Research Papers, 10(2): 46-61.

Levine, R. (1991). Stock markets, growth, and tax policy. Journal of Finance, 46(4): 1445-65.

Levine, R. \& Zervos, S. (1996). Stock market development and long run growth. The World Bank Economic Review, 10(2): 323-39.

Luintel, K. \& Khan, M. (1999). A quantitative reassessment of the finance-growth nexus: evidence from a multivariate VAR. Journal of Development Economics, 60(2): 381-405.

McKinnon, R. (1973). Money and capital in economic development. Washington, Brookings Institution.

Nurudeen, A. (2009). Does stock market development raise economic growth? evidence from Nigeria. The Review of Finance and Banking, 1(1): 15-26.

Olweny, T.O. \& Kimani, D. (2011). Stock market performance and economic growth: empirical evidence from Kenya using causality test approach. Advances in Management \& Applied Economics, 1(3): 153-196.

Pesaran, M.H., and Pesaran, B. (1997). Working with microfit4.0: interactive econometric analysis. Oxford University Press.

Pesaran, M.H., and Shin, Y. (1999). An autoregessive distributed lag modelling approach to cointegration analysis. Chapter 11 in S. Strom (ed.), Econometrics and Economic Theory in the 20 ${ }^{\text {th }}$ Century: The Ragnar Frisch Centennial Symposium. Cambridge University Press, Cambridge.

Pesaran, M.H., Shin, Y., and Smith, R.J. (2001) Bounds testing approaches to the analysis of level relationships. Journal of Applied Econometrics, 16: 289-326.

Schumpeter, J. (1934). The theory of economic development. Cambridge, Harvard University Press.

Shaw, E.S. (1973). Financial deepening in economic development. New York, Oxford University Press. 